\title{
Effect of Storage and Umbel Orders on Seed Quality of European Carrot Cultivar Solan Rachna under Cold Desert Conditions of Himachal Pradesh
}

\author{
Ashok K. Thakur ${ }^{* 1}$, Amit Vikram² ${ }^{2}$ H. S. Kanwar ${ }^{2}$ and R. K. Bhardwaj ${ }^{2}$ \\ ${ }^{1}$ Dept. of Seed Science and Technology, Dr Y S Parmar University of Horticulture and Forestry, Nauni, \\ Solan, H.P. (173 230), India \\ ${ }^{2}$ Dept. of Vegetable Science, Dr Y S Parmar University of Horticulture and Forestry, Nauni, Solan, H.P. (173 230), India \\ ${ }^{4}$ Dept. of Vegetable Science, Dr Y S Parmar University of Horticulture and Forestry, Solan, H.P. (173 230), India
}

\section{Article History}

Manuscript No. AR900

Received in $10^{\text {th }}$ September, 2014

Received in revised form $15^{\text {th }}$ Decemebr, 2014

Accepted in final form $5^{\text {th }}$ January, 2015

\section{Correspondence to}

"E-mail: ashok.horticulture@gmail.com

\section{Keywords}

Cold desert, Daucus carota, seed quality, storage, umbel order

\begin{abstract}
These investigations were carried out to study the effect of umbel orders and storage on seed quality of European carrot cv. Solan Rachna produced and stored in cold desert conditions at RHRSS, Tabo, Lahaul and Spiti, HP during 2008-2012. Significant differences among seeds of different umbel orders were observed with respect to 1000seed weight, seedling length and seed vigour index-I. Heaviest seeds were produced on primary umbels with 1000 -seed weight of $1.53 \mathrm{~g}$ followed by secondary umbel seeds $(1.49 \mathrm{~g})$, mixed seed lot $(1.42 \mathrm{~g})$ and tertiary umbel seeds $(1.19 \mathrm{~g})$. Germination showed a progressive decrease with increasing umbel order. The longest seedlings $(10.60 \mathrm{~cm})$ were observed in primary umbel seeds. Similarly, the most vigorous seeds were borne on primary umbels. Storage period affected physiological traits like germination, seedling length and seed vigour. The highest germination $(68.67 \%)$ was observed in the fresh seeds and lowest $(30.33 \%)$ in oldest seeds. The longest seedlings were produced by the fresh seed and the length decreased with the storage period of the seed lot. Seed Vigour Index-I decreased with storage period of the seeds. Interaction of umbel order and storage period of carrot seed significantly affected physiological quality. The longest seedlings $(11.71 \mathrm{~cm})$ were produced by the youngest seeds of primary umbel, whereas the shortest seedlings were produced by the mixed lot seed stored for three years. Seedling length decreased significantly with increasing storage period within umbel orders. Primary umbel order seeds had least germination reduction with increasing storage period. Vigour deterioration was more pronounced in seeds of inferior umbel orders.
\end{abstract}

\section{Introduction}

European carrots (Daucus carota L.) are widely grown for its highly nutritious roots. These contain approximately $9000 \mathrm{IU}$ beta-carotene per $100 \mathrm{~g}$ of edible portion. In addition, European carrots are much more flavourful and rich in many essential minerals and dietary fibre. However, the seed production of this crop can only be done in temperate region where vernalisation requirement of roots for flower stalk induction can be met. In addition, cool summers are also a pre-requisite for quality seed production. Due to these limitations seed of European carrots are difficult and expensive to produce. Besides this, being a member of Umbelliferae the seeds are borne in umbels of various orders and there is variation in seed size, germination and vigour of seeds borne in different umbel orders. (Hawthorn and Toole, 1962; Castro and Andrews, 1971; Gray and Steckel, 1983; Krarup and Villanueva, 1977; Viggiano, 1984; Nascimento, 1991; Rodo et al., 2001). The heterogeneity in seed lot causes reduction in seed quality and results in many problems with respect to physiological and physical quality of seed thereby affecting plant stand, uniformity and yield. The quality is further reduced due to deterioration of seed in storage. Seed deterioration is a major problem in crop production and about $25 \%$ of the annual value of the seeds in inventory is lost (McDonald and Nelson, 1986). The storage potential and deterioration varies within seed lot and even individual seed has differential behaviour (Delouche, 1973). This differential further aggravates the problem of heterogeneity within the same seed lot. The heterogeneity in carrot seed is a bigger problem when seed lots are smaller in size. This is particularly 
so in case of carrot which is a highly cross pollinated crop and a minimum population size is required to maintain genetic purity and prevent loss of alleles during storage of germplasm. The rate of deterioration of seed quality is certainly reduced under low temperature and relative humidity conditions, but it adds to the cost of seed. The cold desert region of Himachal Pradesh, where low temperature and low relative humidity is a natural phenomenon, offers highly conducive environment for quality seed production and storage of temperate carrot seeds. The present study was aimed to measure the heterogeneity in physical and physiological seed quality and to study the effect of storage of seeds under ambient conditions prevalent in cold desert regions. In this experiment, therefore, the seeds of primary, secondary, tertiary umbel orders and mixed lot stored for different periods were evaluated for various seed quality parameters.

\section{Materials and Methods}

The present investigations were undertaken at Regional Horticultural Research Sub-Station (RHRSS), Tabo, Lahaul \& Spiti, HP, India and Department of Seed Science and Technology, Dr Y S Parmar University of Horticulture and Forestry, Nauni, Solan, HP, India during 2008-2011. The experimental material consisted of seed of European carrot cv. Solan Rachna. The seeds of this cultivar were produced in the years 2008, 2009, 2010 and 2011 at RHRSS, Tabo. The package of practices recommended by Dr Y S Parmar University of Horticulture and Forestry, Nauni, Solan was followed for seed production (Anonymous, 2006). The cultivar was raised in four plots replicated three times every year. Within replication, the seeds of primary, secondary, tertiary and mixed lot were harvested separately from different plots. Three replicates of seeds were separately harvested for each umbel order every year. The crop was raised from the mixed lot of preceding year crop. The seeds were stored under ambient conditions of RHRSS, Tabo, HP, India from 2008 onwards in heat sealed polythene seed bags. The meteorological data for the period of study are given in Table 1.

The magnitude of heterogeneity in physical and physiological quality of carrot seeds was assessed at Department of Seed Science and Technology, YSPUHF, Solan, HP, India. Effect of storage period and umbel order on physical quality parameter viz., seed size and 1000-seed weight and physiological quality parameters viz., seed germination and vigour were investigated.

The 1000-seed weight was measured using precision electronic balance. The seeds for each weighing were counted using INDOSAW computerised seed counter for accurate count. The 1000-seed weight was measured at a uniform moisture content of $8 \%$ for each lot. The seed moisture was determined with a digital non-destructive seed moisture meter before each weighing.

The germination percent was recorded using top of paper method in Petri plates kept in seed germinator with temperature and humidity regulation. The temperature for germination studies was kept at $20^{\circ} \mathrm{C}$ with relative humidity at $80 \%$. For each treatment 100 seeds were kept per replication. The first count was recorded on 7 day and the final count recorded on 14 day. Seeds that showed primary root protrusion were counted as germinated. The seed vigour was measured by calculating the

\begin{tabular}{|c|c|c|c|c|c|c|c|c|c|c|c|c|c|c|c|c|}
\hline \multirow{3}{*}{$\begin{array}{l}\text { Year/ } \\
\text { Month }\end{array}$} & \multicolumn{4}{|c|}{2008} & \multicolumn{4}{|c|}{2009} & \multicolumn{4}{|c|}{2010} & \multicolumn{4}{|c|}{2011} \\
\hline & \multicolumn{2}{|c|}{$\begin{array}{c}\text { Temperature } \\
\left({ }^{\circ} \mathrm{C}\right)\end{array}$} & \multicolumn{2}{|c|}{ R.H. (\%) } & \multicolumn{2}{|c|}{$\begin{array}{c}\text { Temperature } \\
\left({ }^{\circ} \mathrm{C}\right)\end{array}$} & \multicolumn{2}{|c|}{ R.H. (\%) } & \multicolumn{2}{|c|}{$\begin{array}{c}\text { Temperature } \\
\left({ }^{\circ} \mathrm{C}\right)\end{array}$} & \multicolumn{2}{|c|}{ R.H. (\%) } & \multicolumn{2}{|c|}{$\begin{array}{c}\text { Temperature } \\
\left({ }^{\circ} \mathrm{C}\right)\end{array}$} & \multicolumn{2}{|c|}{ R.H. (\%) } \\
\hline & Min. & Max. & in. & Non & Min. & Max. & Min. & $\mathrm{M}$ & Min. & Max. & Min. & Max. & Min. & Max. & Min. & A. \\
\hline Jan & -9.88 & -1.21 & 28.64 & 74.26 & -5.33 & 2.73 & 34.79 & 74.54 & -11.28 & -1.19 & 24.28 & 58.56 & -14.5 & -4.39 & 31.3 & 72.64 \\
\hline Feb & -10.21 & 0.01 & 19.4 & 58.9 & -6.79 & 3.66 & 20.55 & 63.62 & -7.84 & 2.78 & 22.06 & 13 & -9.15 & 77 & 29.55 & 76.51 \\
\hline Mar & 0.98 & 9.96 & 12.03 & 51.12 & -1.93 & 10.02 & 11.30 & 53.60 & -3.73 & 8.67 & 16.94 & 55.08 & -4.76 & 6.65 & 18.94 & 63.56 \\
\hline pr & 0.04 & 12.98 & 15.62 & 60.18 & 1.90 & 13.9 & 13 & 56 & 2.56 & 13.96 & 21.32 & 71.30 & 3. & 15.92 & 9.17 & 49.12 \\
\hline May & 6.40 & 19.78 & 13.39 & 65.68 & 5.49 & 18.11 & 13.04 & 56.06 & 5.94 & 18.95 & 12.41 & 60.93 & 7.09 & 21.3 & 9.41 & 52.97 \\
\hline Jun & 12.04 & 20.66 & 18.11 & 72.07 & 8.24 & 23.37 & 9.26 & 56 & 8.21 & 21.77 & 14.59 & 64.16 & 10.00 & 24.86 & 14.59 & 66.35 \\
\hline Jul & 12.01 & 24.86 & 19.45 & 67.98 & 12.19 & 26.75 & 15.10 & 64.31 & 11.26 & 22.51 & 26.83 & 73.41 & 13.19 & 27.36 & 18.44 & 68.69 \\
\hline Aug & 13.12 & 25.43 & 21.45 & 76.00 & 12.77 & 27.32 & 17.05 & 67.76 & 13.20 & 25.64 & 28.87 & 83.37 & 12.74 & 26.51 & 21.90 & 77.70 \\
\hline Sept & 9.32 & 20.97 & 18.19 & 69.25 & 7.26 & 20.00 & 19.48 & 59.32 & 8.85 & 21.43 & 23.18 & 76.49 & 9.66 & 24.17 & 14.79 & 68.89 \\
\hline Oct & 3.32 & 16.85 & 8.78 & 60.00 & 1.62 & 15.77 & 9.24 & 56.04 & 2.07 & 17.17 & 9.50 & 64.15 & 3.99 & 20.01 & 7.29 & 61.51 \\
\hline Nov & -2.56 & 10.09 & 10.23 & 43.54 & -2.76 & 8.33 & 12.79 & 52.07 & -1.02 & 11.54 & 8.41 & 38.74 & -2.89 & 10.95 & 8.96 & 37.45 \\
\hline Dec & -6.98 & 15.76 & 15.00 & 50.22 & -7.81 & 1.05 & 20.46 & 52.25 & -7.37 & 4.42 & 13.09 & 48.56 & -7.36 & 3.74 & 14.65 & 48.94 \\
\hline
\end{tabular}


Seed Vigour Index-I as suggested by Abdul-Baki and Anderson (1973). The data recorded under the study was subjected to the analysis of variance as per Gomez and Gomez (1983). The statistical analysis of the data was done using SAS 9.3.

\section{Results and Discussion}

\subsection{Seed quality in relation to umbel order}

The analysis of variance depicted significant differences among the seeds of different umbel orders with respect to thousand seed weight, seedling length and seed vigour index-I while the differences in terms of germination percent were statistically non-significant (Table 2). Heaviest seeds were produced on primary umbels with thousand seed weight of $1.53 \mathrm{~g}$ followed by secondary umbel seeds $(1.49 \mathrm{~g})$, mixed seed lot (1.42 g) and tertiary umbel seeds $(1.19 \mathrm{~g})$. The differences in seed germination measured in terms of germination at first count and final count showed a progressive decrease with increasing umbel order. The longest seedlings $(10.60 \mathrm{~cm})$ were observed in the seeds of primary umbel and decreased with umbel order $(9.59 \mathrm{~cm}$ and $8.94 \mathrm{~cm}$ in secondary and tertiary umbel order seeds, respectively). The shortest seedlings $(8.74 \mathrm{~cm})$ were observed in mixed lot seeds. The seed vigour index-I, a function of seedling length and germination, followed the same pattern. Most vigorous seeds were those harvested from primary umbels and the vigour reduced consecutively with umbel order. The overall results depicted that the seeds from superior umbel orders possess higher seed quality and vigour. Carrot seeds from superior umbels have shown better seed quality than those from inferior umbel orders (Nascimento et al., 2012). This superiority is owing to the higher seed size and density, presenting a better seed development (Pereira et al., 2008). Seeds with fully mature embryos and high amounts of reserves are potentially the most vigourous ones (Carvalho

Table 2: Effect of seed umbel order on physical and physiological seed quality of European carrot cv. Solan Rachna

\begin{tabular}{|c|c|c|c|c|c|}
\hline Umbel order & $\begin{array}{c}\text { The } \\
1000 \\
\text { seed } \\
\text { weight } \\
(\mathrm{mg})\end{array}$ & $\begin{array}{c}\text { Germi- } \\
\text { nation } \\
(\%) \\
\text { First } \\
\text { count }\end{array}$ & $\begin{array}{c}\text { Germi- } \\
\text { nation } \\
(\%) \\
\text { Final } \\
\text { count }\end{array}$ & $\begin{array}{l}\text { Seed- } \\
\text { ling } \\
\text { length } \\
(\mathrm{cm})\end{array}$ & $\begin{array}{c}\text { Seed } \\
\text { Vigour } \\
\text { Index I }\end{array}$ \\
\hline Primary & $1.53^{\mathrm{a}}$ & $55.17^{\mathrm{a}}$ & $62.33^{\mathrm{a}}$ & $10.60^{\mathrm{a}}$ & $671.82^{\mathrm{a}}$ \\
\hline Secondary & $1.49^{\mathrm{ab}}$ & $45.17^{\mathrm{a}}$ & $49.17^{\mathrm{a}}$ & $9.59^{b}$ & $475.63^{\mathrm{a}}$ \\
\hline Tertiary & $1.19^{c}$ & $43.33^{\mathrm{a}}$ & $49.00^{\mathrm{a}}$ & $8.94^{c}$ & $441.53^{\mathrm{a}}$ \\
\hline Mixed Lot & $1.42^{\mathrm{b}}$ & $43.33^{\mathrm{a}}$ & $45.83^{\mathrm{a}}$ & $8.74^{\mathrm{c}}$ & $410.36^{\mathrm{a}}$ \\
\hline Mean & 1.41 & 46.75 & 51.58 & 9.47 & 499.19 \\
\hline $\mathrm{SEm} \pm$ & 0.013 & 4.450 & 4.975 & 0.063 & 47.763 \\
\hline $\operatorname{LSD}(p=0.05)$ & 0.076 & 25.703 & 28.738 & 0.362 & 275.899 \\
\hline
\end{tabular}

and Nakagawa, 1983).

\subsection{Effect of storage on seed quality}

The present studies showed that the storage period significantly affected the physiological quality traits like germination, seedling length and the seed vigour. However, non-significant effect of storage was recorded on the seed weight (Table 3). The highest germination, measured as germination at first count and final count was observed in the fresh seeds and decreased with the increase in period of storage. The seedling length observed at the final count on $14^{\text {th }}$ day revealed that the longest seedlings were produced by the fresh seed and the length decreased significantly with the storage period of the seed lot. The seed vigour measured as Seed Vigour Index-I, likewise, showed the significant reduction with storage period of the seeds. When the seed lots are stored for long period, seed vigour tends to decrease which can affect the potential for field establishment negatively (Pereira et al., 2008). The vigour evaluation of carrot seed lots after different storage periods facilitated the comparison of the seed lots (Andrade et al., 1995). This may be of high relevance with respect to the seed storage and its commercial usage.

\subsection{Interaction effects of umbel order and storage on seed quality}

The present studies showed that the interaction of umbel order and storage period of carrot seed significantly affected the physiological seed quality (Table 4). The longest seedlings $(11.71 \mathrm{~cm})$ were produced by the youngest seeds of primary umbel, whereas the shortest seedlings were produced by the mixed lot seed stored for three years. The seedling length decreased significantly with increasing storage period with in the umbel orders (Figure 3). In overall comparison also there was significant reduction in seedling length with increasing storage period. The oldest seed lot of primary umbel had shorter seedlings compared to the youngest seed lot of secondary

Table 3: Effect of storage on physical and physiological seed quality of european carrot $\mathrm{cv}$. solan rachna

\begin{tabular}{|c|c|c|c|c|c|}
\hline $\begin{array}{l}\text { Age of Seed } \\
\text { (Years)/ } \\
\text { Harvest year }\end{array}$ & $\begin{array}{c}\text { The } \\
1000 \\
\text { seed } \\
\text { weight } \\
(\mathrm{mg})\end{array}$ & $\begin{array}{c}\text { Germi- } \\
\text { nation } \\
(\%) \\
\text { First } \\
\text { count }\end{array}$ & $\begin{array}{c}\text { Germi- } \\
\text { nation } \\
(\%) \\
\text { Final } \\
\text { count }\end{array}$ & $\begin{array}{l}\text { Seed- } \\
\text { ling } \\
\text { length } \\
(\mathrm{cm})\end{array}$ & $\begin{array}{c}\text { Seed } \\
\text { Vigour } \\
\text { Index I }\end{array}$ \\
\hline $0(2011)$ & $1.41^{\mathrm{ab}}$ & 65.17 & 68.67 & 10.04 & 694.74 \\
\hline $1(2010)$ & $1.40^{\mathrm{b}}$ & 56.00 & 61.67 & 9.66 & 600.60 \\
\hline $2(2009)$ & $1.42^{\mathrm{a}}$ & 39.67 & 45.67 & 9.28 & 429.83 \\
\hline $3(2008)$ & $1.40^{\mathrm{a}}$ & 26.17 & 30.33 & 8.89 & 274.19 \\
\hline Mean & 1.41 & 46.75 & 51.58 & 9.47 & 499.19 \\
\hline $\mathrm{SEm} \pm$ & 0.013 & 4.450 & 4.975 & 0.063 & 47.763 \\
\hline $\operatorname{LSD}(p=0.05)$ & 0.076 & 25.703 & 28.738 & 0.362 & 275.899 \\
\hline
\end{tabular}


and tertiary umbel orders. The germination data indicated that primary umbel order seeds had least deterioration with corresponding increase in storage period. The deterioration in seed germination was more pronounced in seeds of inferior umbel orders.

The germination of primary umbel seeds was above the Indian Minimum Seed Certification Standards for germination (60\%) up to two years of storage (Figure 1\&2). However, the mixed lot fulfilled this condition up to one year only. The overall comparison of germination and seed vigour index-I depicted that the physiological seed quality was highest in fresh seed lot of primary umbel order that gradually decreased with inferior umbel order and storage period (Figure 4). In order to achieve better performance of stored seed the seeds from superior umbel orders should be selected and stored separately. The primary seed umbel order seed though showed good germination in the third year of storage but the vigour has reduced remarkably. This will certainly result in low performance and poor establishment of seedlings under field conditions. Studies show that the germination of carrot seeds reduces to zero in two years of storage (Andrade et al., 1995), but the lowest germination in the present studies recorded is $24 \%$ in mixed lot stored for three years. This is mainly attributed that the seed was stored in ambient conditions in the dry temperate region having low temperature and low relative humidity.

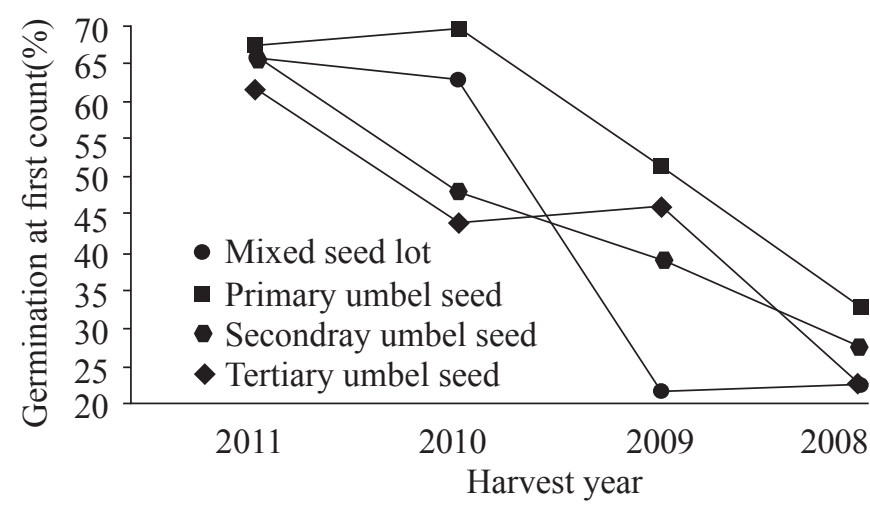

Figure1: Effect of storage on \% germination at first count of different umbel order carrot seed

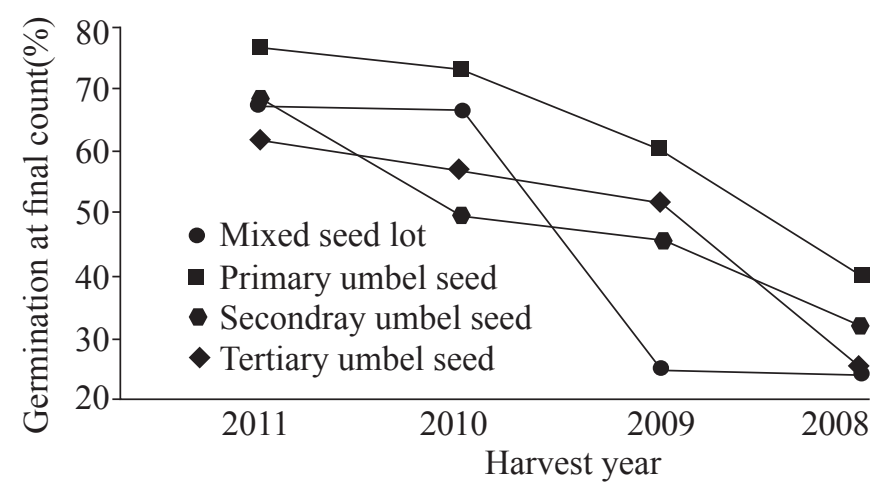

Figure 2: Effect of storage on \% germination at final count of different umbel order carrot seed

\begin{tabular}{|c|c|c|c|c|c|c|}
\hline $\begin{array}{c}\text { Age of Seed (Years)/ } \\
\text { harvest year }\end{array}$ & Umbel order & $\begin{array}{l}\text { The } 1000 \text { seed } \\
\text { weight }(\mathrm{mg})\end{array}$ & $\begin{array}{l}\text { Germination } \\
\text { (\%) First count }\end{array}$ & $\begin{array}{l}\text { Germination } \\
(\%) \text { Final count }\end{array}$ & $\begin{array}{l}\text { Seedling } \\
\text { length }(\mathrm{cm})\end{array}$ & $\begin{array}{l}\text { Seed Vigour } \\
\text { Index I }\end{array}$ \\
\hline $0(2011)$ & Primary & 1.53 & 67.33 & 76.67 & 11.71 & 898.89 \\
\hline 0 & Secondary & 1.50 & 66.00 & 68.67 & 9.99 & 685.21 \\
\hline 0 & Tertiary & 1.19 & 61.33 & 62.00 & 9.22 & 571.43 \\
\hline 0 & Mixed Lot & 1.42 & 66.00 & 67.33 & 9.25 & 623.40 \\
\hline $1(2010)$ & Primary & 1.51 & 69.33 & 73.33 & 10.84 & 793.57 \\
\hline 1 & Secondary & 1.48 & 48.00 & 50.00 & 9.65 & 484.32 \\
\hline 1 & Tertiary & 1.18 & 44.00 & 56.67 & 9.13 & 517.61 \\
\hline 1 & Mixed Lot & 1.41 & 62.67 & 66.67 & 9.03 & 606.88 \\
\hline $2(2009)$ & Primary & 1.54 & 51.33 & 60.33 & 10.03 & 601.55 \\
\hline 2 & Secondary & 1.51 & 39.33 & 46.00 & 9.51 & 437.44 \\
\hline 2 & Tertiary & 1.20 & 46.00 & 52.00 & 8.87 & 461.33 \\
\hline 2 & Mixed Lot & 1.43 & 22.00 & 25.33 & 8.69 & 219.00 \\
\hline 3 (2008) & Primary & 1.52 & 32.67 & 40.00 & 9.81 & 393.28 \\
\hline 3 & Secondary & 1.49 & 27.33 & 32.00 & 9.18 & 295.56 \\
\hline 3 & Tertiary & 1.18 & 22.00 & 25.33 & 8.55 & 215.73 \\
\hline 3 & Mixed Lot & 1.41 & 22.67 & 24.00 & 8.01 & 192.17 \\
\hline \multicolumn{2}{|l|}{ Mean } & 1.41 & 46.75 & 51.58 & 499.19 & 9.47 \\
\hline \multicolumn{2}{|c|}{$\mathrm{SE}(\mathrm{m}) \pm$} & 0.026 & 8.899 & 9.950 & 0.125 & 95.526 \\
\hline \multicolumn{2}{|c|}{$\operatorname{LSD}(p=0.05)$} & 0.076 & 25.703 & 28.738 & 0.362 & 275.899 \\
\hline
\end{tabular}




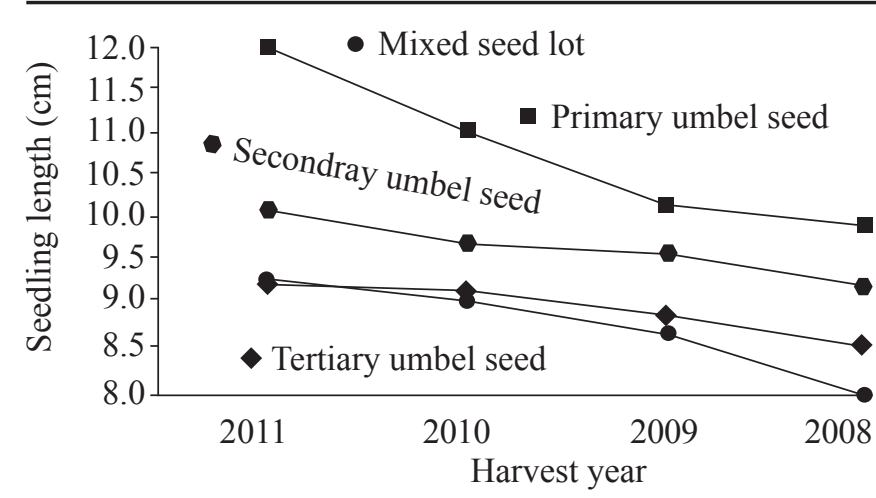

Figure 3: Effect of storage on seedling length of different umbel order carrot seed

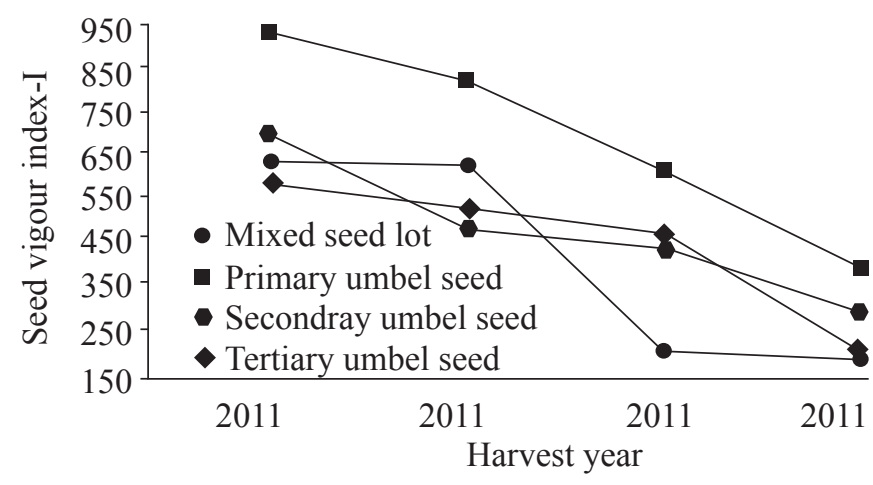

Figure 4: Effect of storage on seed vigour of different umbel order carrot seed

\section{Conclusion}

There was significant effect of umbel orders and storage duration on the physical and physiological seed quality traits in temperate carrots. Older seeds from primary and secondary umbel orders showed better performance than those from tertiary umbel orders. The present studies also indicated that it would be desirable to use seeds from primary and secondary umbels for storage and to use in subsequent growing seasons. Beneficial effects of the use of superior umbel order seeds for maintaining active germplasm collections under ambient conditions are also apparent from the present studies.

\section{References}

Abdul-Baki, A., Anderson, J.D., 1973. Vigor determination in soybean seed by multiple criteria. Crop Science 13, 630-633.

Andrade, R.N.B., Santos, D.S.B., Santos, F.B.G., Vera, D.C., 1995. Correlacao entre testes de vigor em sementes de cenoura armazenadas por diferentes periodos. Pesquisa Agropecuaria Gaucha 1, 153-162.

Anonymous. 2006. Package of practices for vegetable crops in Himachal Pradesh. Directorate of Extension Education, UHF, Solan.
Carvalho, N.M., Nakagawa, J., 1983. Sementes: ciencia, tecnologia e producao. Campinas: Fundacao Cargil. 429.

Castro, L.A.B., Andrews, C.H., 1971. Fatores influenciando o rendimento e qualidade de sementes de cenoura (Daucus carota L.). Arquivos da Universidade Federal Rural do Rio de Janeiro 1, 19-28.

Delouche, Y.C., Baskin, C., 1973. Accelerated ageing techniques for predicting the relative storability of seeds lots. Seeds Science and Technology 1, 427-452.

Gomez, K.A., Gomez, A.A., 1983. Statistical Procedures for Agricultural Research. John Wiley \& Sons. Inc. New York. 680.

Gray, D., Steckel, J.R.A., 1983. Some effects of umbel order and harvest date on carrot seed variability and seedling performace. Journal of Horticultural Science 58, 73-82.

Hawthorn, L.R., Toole, E.H., Toole, V.K., 1962. Yield and variability of carrot seeds are affected by position of umbel and time of harvest. Proceedings of the American Society of Horticultural Science 80, 401-107.

Krarup, A., Villanueva, G., 1977. Produccion de semilla de zanahoria: relacion entre el tamano del embrion y el porcentaje de germinacion de semillas provenientes de distintos ordenes florales. Agro Sur 5, 45-48.

Malik, B.S., Kanwar, J.S., 1969. Effect of seed size and stage of harvest of carrot seed on the germination, growth and yield of carrot. Indian Journal of Agricultural Sciences 69, 603-610.

McDonald, M.B., Nelson, C.J., 1986. Physiology of Seed Deterioration.CSSA Special Publication No. 11. Crop Science Society of America, Madison, WI, USA.

Nascimento, W.M., 1991. Effect of umbel order in production and quality of carrot seeds. Pesquisa Agropecuaria Brasileira 13, 131-133.

Nascimento, W.M., 1991. Efeito da ordem das umbelas na producao e qualidade de sementes de cenoura. Revista Brasileira de Sementes 13, 131-133.

Nascimento. W.M., Pereira, R.S., Vieira, J.V., Cantliffe, D.J., 2012. Carrot seed germination at high temperature conditions. Acta Horticulturae 936, 133-138.

Pereira, R.S., Nascimento, W.M., Vierira, J.V., 2008. Carrot seed germination and vigor in response to temperature and umbel orders. Scientific Agriculture 65, 145-150.

Rodo, A.B., Perleberg, C.S., Torres, S.B., Gentil, D.F.O., Neto, J.T., 2001. Qualidade fisiologica e tamanho de sementes de cenoura. Scientia Agricola 58, 201-204.

Viggiano, J., 1984. Producao de sementes de algumas umbeliferas. Informe Agropecuario 10, 60-65. 